Johnson \& Johnson, Roche, Sanofi, Guigai, Roche, Boehringer Ingelheim, UCB, MSD, Astra-Zeneca, Astellas, Gilead, Shue Fen Luo: None declared, Yeong-Jian Jan Wu Speakers bureau: Pfizer, Lilly, Novartis, Abbvie, Aisha Lateef: None declared, Jiacai Cho: None declared, Laniyati Hamijoyo Speakers bureau: Pfizer, Novartis, Abbot, Chak Sing Lau Shareholder of: Pfizer, Sanofi, and Janssen, Sandra Navarra Speakers bureau: Pfizer, Johnson \& Johnson, Novartis, Astellas, Grant/research support from: Astellas, Johnson \& Johnson, Leonid Zamora: None declared, Zhanguo Li Speakers bureau: Eli, Lilly, Novartis, GSK, AbbVie, Paid instructor for: Pfizer, Roche, Johnson., Consultant of: Lilly, Pfizer, Grant/research support from: Pfizer, Yuan An: None declared, Sargunan Sockalingam Speakers bureau: Pfizer, Roche, Novartis, Grant/research support from: Roche and Novartis, Yasuhiro Katsumata Speakers bureau: Chugai Pharmaceutical Co., Ltd., Glaxo-Smithkline K.K., and Sanofi K.K., masayoshi harigai Speakers bureau: AbbVie Japan GK, Ayumi Pharmaceutical Co., Boehringer Ingelheim Japan, Inc.,Bristol Myers Squibb Co., Ltd., Chugai Pharmaceutical Co., Ltd., Eisai Co., Ltd., Eli Lilly Japan K.K., GlaxoSmithKline K.K., Kissei Pharmaceutical Co., Ltd., Pfizer Japan Inc., Takeda Pharmaceutical Co., Ltd., and Teijin Pharma Ltd., Consultant of: AbbVie, Boehringer-ingelheim, Bristol Myers Squibb Co., Kissei Pharmaceutical Co.,Ltd. and Teijin Pharma., Grant/research support from: AbbVie Japan GK, Asahi Kasei Corp., Astellas Pharma Inc., Ayumi Pharmaceutical Co., Bristol Myers Squibb Co., Ltd., Chugai Pharmaceutical Co., Daiichi-Sankyo, Inc.,Eisai Co., Ltd., Kissei Pharmaceutical Co., Ltd., Mitsubishi Tanabe Pharma Co., Nippon Kayaku Co., Ltd., Sekiui Medical, Shionogi \& Co., Ltd., Taisho Pharmaceutical Co., Ltd., Takeda Pharmaceutical Co., Ltd., and Teijin Pharma Ltd., Yanjie Hao: None declared, Zhuoli Zhang Speakers bureau: Norvatis, GSK, Pfizer, Jun Kikuchi: None declared, Tsutomu Takeuchi Speakers bureau: AbbVie AYUMI Pharmaceutical Corp. Bristol-Myers Squibb Chugai Pharmaceutical Co, Ltd. Daiichi Sankyo Co., Ltd. Eisai Co., Ltd. Eli Lilly Japan, Gilead Sciences, Inc. Mitsubishi-Tanabe Pharma Corp. Pfizer Japan Inc. Sanofi K.K., Consultant of: Astellas Pharma, Inc. Chugai Pharmaceutical Co, Ltd. Eli Lilly Japan, Mitsubishi-Tanabe Pharma Corp., Grant/research support from: AbbVie, Asahikasei Pharma Corp. Chugai Pharmaceutical Co, Ltd. Mitsubishi-Tanabe Pharma Corp. Sanofi K.K., BMDB Basnayake: None declared, Fiona Goldblatt: None declared, Madelynn Chan Speakers bureau: AbbVie, Novartis, Consultant of: Pfizer, Eli-Lilly, Kristine Ng Speakers bureau: Abbvie, Novartis, Janssen, Sang-Cheol Bae: None declared, Shereen Oon: None declared, Sean O'Neill Consultant of: GSK, Kathryn Gibson Speakers bureau: UCB, Consultant of: Novartis, Janssen, Grant/research support from: Novartis, Sunil Kumar: None declared, Nicola Tugnet: None declared, Yoshiya Tanaka Speakers bureau: Daiichi-Sankyo, Eli Lilly, Novartis, YL Biologics, Bristol-Myers, Eisai, Chugai, Abbvie, Astellas, Pfizer, Sanofi, Asahi-kasei, GSK, Mitsubishi-Tanabe, Gilead, Janssen, Grant/research support from: Abbvie, Mitsubishi-Tanabe, Chugai, Asahi-Kasei, Eisai, Takeda, Daiichi-Sankyo, Mandana Nikpour Speakers bureau: Actelion, GSK, Janssen, Pfizer, UCB, Paid instructor for: UCB, Consultant of: Actelion, Boehringer Ingelheim, Certa Therapeutics, Eli Lilly, GSK, Janssen, Pfizer, UCB, Grant/research support from: Actelion, Astra Zeneca, BMS, GSK, Janssen, UCB, Eric F. Morand Speakers bureau: AstraZeneca, Paid instructor for: Eli Lilly, Consultant of: AstraZeneca, Amgen, Biogen, BristolMyersSquibb, Eli Lilly, EMD Serono, Genentech, Janssen, Grant/research support from: AstraZeneca, BristolMyersSquibb, Eli Lilly, EMD Serono, Janssen.

DOI: 10.1136/annrheumdis-2021-eular.938

\section{POS0029 INCIDENCE AND TREATMENT PENETRATION OF RHEUMATOID ARTHRITIS IN NORWAY - A NATIONWIDE REGISTER LINKAGE STUDY}

A. Kerola ${ }^{1,2}$, J. Sexton $^{1}$, G. Wibetoe ${ }^{1}$, S. Rollefstad ${ }^{1}$, C. S. Crowson ${ }^{3}$, E. Haavardsholm ${ }^{1}$, T. K. Kvien ${ }^{1}$, A. G. Semb ${ }^{1} .{ }^{1}$ Diakonhjemmet Hospital, Division of Rheumatology and Research, Oslo, Norway; ${ }^{2}$ Päijät-Häme Joint Authority for Health and Wellbeing, Rheumatology, Lahti, Finland; ${ }^{3}$ Mayo Clinic, Department of Quantitative Health Sciences, Rochester, Minnesota, United States of America

Background: Incidence of rheumatoid arthritis (RA) in Norway has not been evaluated in a nationwide setting.

Objectives: To estimate the incidence of RA and real-life penetration of disease-modifying antirheumatic drug (DMARD) use in Norway.

Methods: The Norwegian Cardio-Rheuma register comprises pseudonymized data from nationwide registries including the total Norwegian population $\geq 18$ years during 2008-2017. Demographic and socioeconomic data were retrieved from the National Population Register and Statistics Norway. Data on public or private somatic specialized care episodes were collected from the Norwegian Patient register (NPR) (ICD-10 codes for diagnoses and medical procedure codes for biologic DMARD infusions). Dispensed DMARD prescriptions were captured from the Norwegian Prescription Database. RA cases were defined as persons with NPR records of all of the following: 1) 1st episode with ICD-10 code M05/M06 as main or contributory diagnosis (index date), 2) 2nd episode with code M05/M06 within 2-year period following index date, 3) M05/M06 recorded in an internal medicine or rheumatology department during the 2-year period. Years 2008-2010 served as a look-back period to identify prevalent RA cases. To estimate person-years (pyrs) at risk, we calculated number of persons aged $\geq 18$ living in Norway on the $1^{\text {st }}$ of January of each year 2011-2015 and multiplied it by one year (prevalent RA cases excluded). Standardized estimates were calculated with 5-year age groups using Norwegian adult population $1^{\text {st }}$ of January 2015 as the standard.

Results: Between 2011 and 2015, 9,493 persons fulfilled the RA definition (62.4\% seropositive based on ICD-10 codes). Incidence rate was 49/100,000 pyrs (32 in men and 65 in women). A sensitivity analysis excluding cases who had dispensed DMARDs $>12$ months before index date yielded 8,125 RA cases (incidence 42/100,000 pyrs). Whereas absolute number of incident cases was highest among those aged 60-69 in both sexes, incidence was highest among those aged 70-79 (Figure 1). Both crude and age- and sex-standardized incidences were lower among persons with higher education level (crude/standardized incidence per 100,000 pyrs for those below upper secondary education $60 / 57$; upper secondary or post-secondary non-tertiary education 53/52; higher education 36/39). Of incident cases, 94\% received any DMARD treatment or glucocorticoids, $78 \%$ methotrexate, and $17 \%$ biologic DMARDs within 2 years after index date (Table 1)

Conclusion: Contemporary register-based estimate of RA incidence in Norway is comparable to other Nordic countries. ${ }^{1,2}$ In line with treatment recommendations, methotrexate is the most commonly used DMARD in the initial treatment strategy in Norway. One in six patients used a biologic DMARD within 2 years from 1st recorded RA diagnosis.

\section{REFERENCES:}

[1] Eriksson JK, Neovius M, Ernestam S et al. Incidence of rheumatoid arthritis in Sweden: a nationwide population-based assessment of incidence, its determinants, and treatment penetration. Arthritis Care Res 2013;65:870-878.

[2] Puolakka K, Kautiainen $\mathrm{H}$, Pohjolainen $\mathrm{T}$ et al. Rheumatoid arthritis remains a threat to work productivity: a nationwide register-based incidence study from Finland. Scand J Rheumatol 2010;39:436-438.

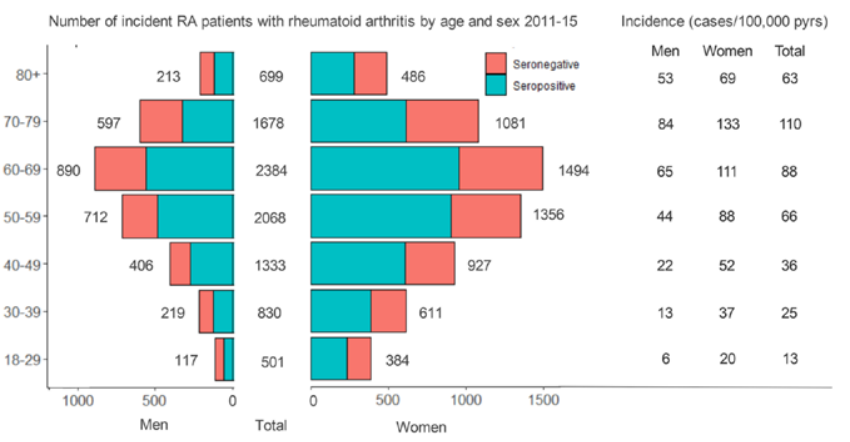

Figure 1.

Table 1. Characteristics and treatment penetration of incident RA patients 2011-2015

\begin{tabular}{|c|c|c|}
\hline & All & $\begin{array}{l}\text { Excluding cases with } \\
\text { DMARDs }>12 \text { months } \\
\text { before index date }\end{array}$ \\
\hline $\mathbf{N}$ & 9493 & 8125 \\
\hline Women, n (\%) & $6339(66.8)$ & $5379(66.2)$ \\
\hline Age at index date, median (IQR) & $60.5(48.5-70.5)$ & $60.8(48.8-70.9)$ \\
\hline RF positive, n (\%) & $5927(62.4)$ & $5193(63.9)$ \\
\hline Use of DMARDs after index date, $n(\%)$ & 12 months 24 months & 12 months 24 months \\
\hline Any conventional DMARD & 7797 (82.1) $8023(84.5)$ & $6682(82.2) 6855(84.4)$ \\
\hline Methotrexate & 7133 (75.1) $7402(78.0)$ & $6228(76.7) 6436(79.2)$ \\
\hline Sulfasalazine & $902(9.5) \quad 1218(12.8)$ & 745 (9.2) 1034 (12.7) \\
\hline Any biologic DMARD & $1102(11.6) \quad 1642(17.3)$ & 1219 (15.0) \\
\hline TNF-inhibitors & 1006 (10.6) 1513 (15.9) & $690(8.5) \quad 1130(13.9)$ \\
\hline Oral glucocorticoids & 6524 (68.7) 6974 (73.5) & 5858 (72.1) 6199 (76.3) \\
\hline Any DMARD or glucocorticoids & 8789 (92.6) 8957 (94.4) & 7498 (92.3) 7639 (94.0) \\
\hline
\end{tabular}


Acknowledgements: This work has been supported by a research grant from FOREUM Foundation for Research in Rheumatology.

Disclosure of Interests: Anne Kerola Speakers bureau: Boehringer-Ingelheim, Consultant of: Pfizer, Gilead, Boehringer-Ingelheim, Joseph Sexton: None declared, Grunde Wibetoe: None declared, Silvia Rollefstad: None declared, Cynthia S. Crowson: None declared, Espen Haavardsholm: None declared, Tore K. Kvien Speakers bureau: Amgen, Celltrion, Egis, Evapharma, Ewopharma, Hikma, Oktal, Sandoz, Sanofimgen, Celltrion, Egis, Evapharma, Ewopharma, Hikma, Oktal, Sandoz, Sanofi, Consultant of: AbbVie, Amgen, Biogen, Celltrion, Eli Lilly, Gilead, Mylan, Novartis, Pfizer, Sandoz, Sanofi, Grant/research support from: research funding to Diakonhjemmet Hospital from AbbVie, Amgen, BMS, MSD, Pfizer and UCB, Anne Grete Semb Speakers bureau: AbbVie, Bayer, Lilly, Novartis, and Sanofi, Consultant of: Sanofi, Grant/research support from: collaborative research support from Lilly, outside the submitted work.

DOI: 10.1136/annrheumdis-2021-eular.975

\section{POS0030 SARCOIDOSIS INCIDENCE IN A NORTHERN SPANISH HEALTH REGION.}

C. Álvarez-Reguera ${ }^{1}$, R. Fernández-Ramón², J. J. Gaitán-Valdizán², J. L. Martín-Varillas ${ }^{3}$, L. Sanchez-Bilbao ${ }^{1}$, D. Martínez-López ${ }^{3}$, I. GonzálezMazón ${ }^{1}$, R. Demetrio-Pablo², M. Á. González-Gay ${ }^{1}$, R. Blanco ${ }^{1} .{ }^{1}$ Hospital Universitario Marqués de Valdecilla, Rheumatology, Santander, Spain; ${ }^{2}$ Hospital Universitario Marqués de Valdecilla, Ophthalmology, Santander, Spain;

${ }^{3}$ Hospital de Sierrallana, Rheumatology, Torrelavega, Spain

Background: Sarcoidosis is a systemic and potentially severe disease (1). Its incidence varies widely worldwide.

Objectives: The aim of this study was to estimate the sarcoidosis incidence in a Northern Spanish population-based cohort.

Methods: All incident cases of sarcoidosis between January 1999 and December 2019 in a tertiary hospital were reviewed. Inclusion criteria were a) diagnosis of sarcoidosis according to ATS/ERS/WASOG (Eur Respir J. 1999; 14:735-7) and b) patients residing in our health region. Incidence between 1999 and 2019 was estimated by sex, age, and year of diagnosis.

Results: From a total of 384 patients diagnosed with sarcoidosis, 234 (129 women/ 105 men) met the inclusion criteria and were finally included in the study. Mean age of the cohort at diagnosis was $48.43 \pm 14.83$ years $(46.95 \pm 14.50$ in males; $49.63 \pm 15.04$ in females, $p=0.12$ ). Annual incidence during 1999-2019 period was 3.56 per 100,000 population (3.32 per 100,000 in males and 3.72 per 100,000 in females). An upward trend in annual incidence over time was observed with rates ranging from 1.73 per 100,000 inhabitants in 1999 to 6.91 per 100,000 inhabitants in 2016 (Figure 1). Overall, sarcoidosis was predominantly diagnosed during middle adulthood. A bimodal distribution of age-specific incidence rates was observed in both sexes with two peaks in the age groups of $30-39(4.98$ per 100,000) and 60-69 years $(5.12$ per 100,000$)$ in men, and in $40-49(6.45$ per 100,000$)$ and 60-69 years $(5.94$ per 100,000$)$ in women.

Comparative studies with other regions are summarize in Table 1.

Conclusion: A progressive increase in incident sarcoidosis is observed. The estimated incidence of sarcoidosis in this study $(3.56$ per 100,000) was like that of other Mediterranean countries (2). No gender predominance was observed. Demographics variations, changes in practice patters or diagnostic test improvements could explain the upward trend in sarcoidosis incidence detected in our study. Consistent with previous studies, male presented an incidence peak 10 years earlier than female (3-5).

\section{REFERENCES:}

[1] Riancho-Zarrabeitia L, et al. Clin Exp Rheumatol 2014; 32(2): 275-84. PMID: 24321604

[2] Brito-Zerón P, et al. Clin Exp Rheumatol. 2019;37(6):1052-64.

[3] Arkema E V., et al. Eur Respir J. 2016;48(6):1690-9.

[4] Yoon H, et al. Am J Respir Crit Care Med. 2018;197(MeetingAbstracts):1-8.

[5] Ungprasert P, et. Mayo Clin Proc. 2016 Feb;91(2):183-8.
A

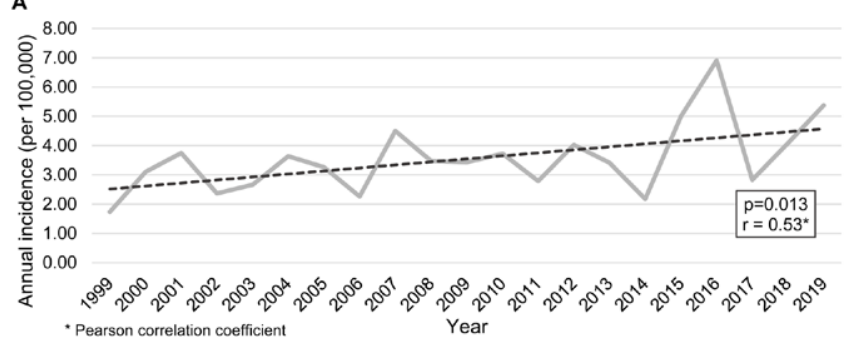

Figure 1. Annual incidence of sarcoidosis in 1999-2019 (A)

Table 1. Sarcoidosis incidence rates reported in the literature.

\begin{tabular}{|c|c|c|c|c|}
\hline Study, year & Country, data source & Time period & Incident cases & $\begin{array}{c}\text { Incidence } \\
\text { per 100,000 } \\
\text { persons-year }\end{array}$ \\
\hline Pietinalho, 1995 & $\begin{array}{c}\text { Finland, hospital } \\
\text { database }\end{array}$ & 1984 & 1,378 & 11.4 \\
\hline Pietinalho, 1995 & $\begin{array}{l}\text { Japan, Hokkaido, hospital } \\
\text { database }\end{array}$ & 1984 & 288 & 1.0 \\
\hline Yigla, 2002 & Israel, hospital database & 1980-1996 & 120 & 0.8 \\
\hline Byg, 2003 & $\begin{array}{c}\text { Denmark, Danish } \\
\text { National Patient } \\
\text { Registry }\end{array}$ & $1980-1994$ & 5,536 & 7.2 \\
\hline Gribbin, 2006 & $\begin{array}{c}\text { UK, Health Improvement } \\
\text { Network }\end{array}$ & $1990-2003$ & 1,019 & 5.0 \\
\hline Gillman, 2007 & $\begin{array}{c}\text { Australia, Victoria, hospi- } \\
\text { tal database }\end{array}$ & $1995-2005$ & 122 & $4.4-6.3$ \\
\hline $\begin{array}{l}\text { Haraldsdottir, } \\
2007\end{array}$ & $\begin{array}{c}\text { Iceland, hospital } \\
\text { database }\end{array}$ & $1981-2003$ & 235 & 3.8 \\
\hline Musellin, 2009 & $\begin{array}{c}\text { Turkey, healthcare } \\
\text { providers }\end{array}$ & $2004-2006$ & 293 & 4.0 \\
\hline $\begin{array}{l}\text { Deubelbeiss, } \\
2010\end{array}$ & $\begin{array}{l}\text { Switzerland, Swiss } \\
\text { Federal Office for } \\
\text { Statistics }\end{array}$ & $2002-2005$ & 2,925 & 7.0 \\
\hline Kowalska, 2014 & $\begin{array}{l}\text { Poland, Katowice, } \\
\text { National Health Fund }\end{array}$ & $2006-2010$ & 1,217 & $3.8-4.5$ \\
\hline Arkema, 2016 & $\begin{array}{c}\text { Sweden, National Patient } \\
\text { Register }\end{array}$ & 2003-2013 & 10,787 & $10.4-14.8$ \\
\hline $\begin{array}{l}\text { Baughman, } \\
2016\end{array}$ & $\begin{array}{c}\text { USA, Optum Health Care } \\
\text { Database }\end{array}$ & $2010-2013$ & 29,372 & $\begin{array}{c}\text { African American: } \\
\text { 17.8; Caucasian: } \\
\text { 8.1; Hispanic: } \\
\text { 4.3; Asian: } 3.2\end{array}$ \\
\hline $\begin{array}{l}\text { Duchemann, } \\
2017\end{array}$ & $\begin{array}{c}\text { France, Seine-Saint- } \\
\text { Denise County }\end{array}$ & 2012 & 361 & 4.9 \\
\hline $\begin{array}{l}\text { Škopljanac, } \\
2017\end{array}$ & $\begin{array}{c}\text { Croatia, Split- Dalmatia } \\
\text { County, hospital } \\
\text { database }\end{array}$ & $1986-2015$ & 318 & $3.1-3.4$ \\
\hline Yoon, 2018 & $\begin{array}{c}\text { Korea, National Health } \\
\text { Insurance }\end{array}$ & $2007-2016$ & 4,791 & 0.85 \\
\hline Fidler, 2019 & $\begin{array}{l}\text { Canada, Ontario, health } \\
\text { administrative data }\end{array}$ & $1996-2015$ & 18,550 & $6.8-7.9$ \\
\hline $\begin{array}{l}\text { Fernandez, } \\
2011\end{array}$ & $\begin{array}{c}\text { Spain, Leon, hospital } \\
\text { database }\end{array}$ & $2001-2008$ & 118 & 4.51 \\
\hline $\begin{array}{l}\text { Present study, } \\
2020\end{array}$ & $\begin{array}{c}\text { Spain, Santander, hospi- } \\
\text { tal database }\end{array}$ & $1999-2019$ & 234 & 3.56 \\
\hline
\end{tabular}

Disclosure of Interests: Carmen Álvarez-Reguera: None declared, Raúl Fernández-Ramón: None declared, Jorge Javier Gaitán-Valdizán: None declared, José Luis Martín-Varillas: None declared, Lara Sanchez-Bilbao: None declared, David Martínez-López: None declared, Iñigo González-Mazón: None declared, Rosalía Demetrio-Pablo: None declared, Miguel Á. González-Gay Speakers bureau: Abbvie, Pfizer, Roche, Sanofi and MSD., Grant/research support from: Abbvie, MSD, Jansen and Roche, Ricardo Blanco Speakers bureau: Abbvie, Pfizer, Roche, Bristol-Myers, Janssen, Lilly and MSD., Grant/research support from: Abbvie, MSD and Roche. DOI: 10.1136/annrheumdis-2021-eular.1870 